\title{
Branchial cleft cyst presenting as metastatic squamous carcinoma in fine needle aspirates: report of three cases
}

\author{
İnce iğne aspiratlarında metastatik yassı epitel hücreli karsinom olarak saptanan \\ brankiyal yarık kisti: Üç olgu sunumu \\ Murat Songu', Hale Aslan', Sinan Başoğlu', Sedat Öztürkcan', Demet Etit² \\ ${ }^{1}$ Department of Otorbinolaryngology, İzmir Atatiirk Research and Training Hospital, Katip Çelebi University, Izmir, Turkey \\ ${ }^{2}$ Department of Pathology, Izmir Ataturk Training and Research Hospital, İzmir, Turkey
}

\begin{abstract}
A subset of metastatic squamous cell carcinoma of the head and neck presents as cystic masses in the neck. Often, distinguishing between these cystic metastases of squamous cell carcinoma from benign cystic neck lesions, such as branchial cleft cyst, can be very challenging. Squamous lining cells in benign cystic lesions may exhibit significant cytologic atypia, raising concern for squamous cell carcinoma. The challenge in distinguishing benign from malignant cystic squamous lesions of the neck is made more difficult when evaluating fine needle aspiration biopsies given the limited sample size. Herein, three patients with branchial cleft cysts are presented. All were initially diagnosed as metastatic squamous cell carcinomas. The importance of interpretation of fine needle aspiration cytology by an experienced cytologist is emphasized to avoid the possibility of excising metastatic squamous cell carcinomas, which could lead to unnecessary surgical procedures such as radical neck dissection.
\end{abstract}

Key words: Branchial cleft cyst, fine needle aspiration, metastatic squamous cell carcinoma.

Branchial cleft cysts (BCC) are relatively uncommon anomalies of the soft tissues of the neck, typically found in the angle between the sternocleidomastoid muscle and the mandible. The origin of the cysts is uncertain. ${ }^{[1]}$ The natural history of upper aerodigestive tract malignancy is of metastasis to cervical lymph nodes. Occasionally, these neck nodes may be the first mode of presentation. ${ }^{[2]}$

Fine-needle aspiration (FNA) cytology has been shown to be very useful in the preoperative evaluation of neck masses. ${ }^{[1]}$ Most cases of solid metastatic squamous cell carci-

\begin{abstract}
Özet
Baş ve boynun metastatik skuamöz karsinomunun bir alt kümesi boyunda kistik kitlelerle ortaya çıkmaktadır. Sıklıkla yassı epitel hücreli karsinomun bu kistik metastazlarını brankiyal yarık kist gibi iyi huylu kistik boyun lezyonlarından ayırt etmek çok zor olabilmektedir. İyi huylu kistik lezyonların iç yüzeyini kaplayan yassı epitel hücreler önemli hücre atipisi gösterebilerek yassı epitel hücreli karsinomdan kaygılanılmasına neden olurlar. Kısıtlı sayıda numune alınan ince iğne biyopsilerini değerlendirirken boynun iyi ve kötü huylu kistik skuamöz lezyonları arasında ayrım yapmak daha çok zorlaşmaktadır. Burada brankiyal yarık kistleri olan üç hasta sunulmaktadır. Hepsine başlangıçta metastatik yassı epitel hücreli karsinom tanısı konmuştu. Gereksiz radikal boyun diseksiyonu gibi cerrahi prosedürlerin uygulanmasina yol açabilen metastatik yassı epitel hücreli karsinom eksizyonu ihtimalinden kaçınmak için deneyimli bir sitolog tarafindan ince iğne aspirasyon sitolojisinin yorumlanmasının önemi vurgulanmaktadır.
\end{abstract}

Anahtar sözcükler: Brankiyal yarık kist, ince iğne biyopsisi, metastatik yassı epitel hücreli karsinom.

noma (SCC) can be accurately diagnosed by FNA; however, in cystic lesions, the cytologic distinction of SCC from benign squamous cell lesions, particularly the ones with superimposed inflammatory atypia, can be diagnostically very challenging. ${ }^{[2]}$ Squamous cells in inflamed BCC can show significant cytologic atypia and nuclear hyperchromatism and, therefore, can be easily confused with cystic metastatic SCC to lymph nodes. ${ }^{[3]}$ Conversely, cells from metastatic, cystic, well differentiated SCC can be cytologically bland and may be difficult to distinguish from BCC. ${ }^{[4]}$

\footnotetext{
Correspondence: Murat Songu, MD. Department of Otorhinolaryngology, İzmir Atatürk Research and Training Hospital, Katip Çelebi University, Polat Caddesi, 35360, İzmir, Turkey. e-mail: songumurat@yahoo.com
}

Received: December 19, 2012; Accepted: January 22, 2013; Published online: May 4, 2013
Online available at: www.jmedupdates.org doi:10.2399/jmu.2013001007 QR code: 

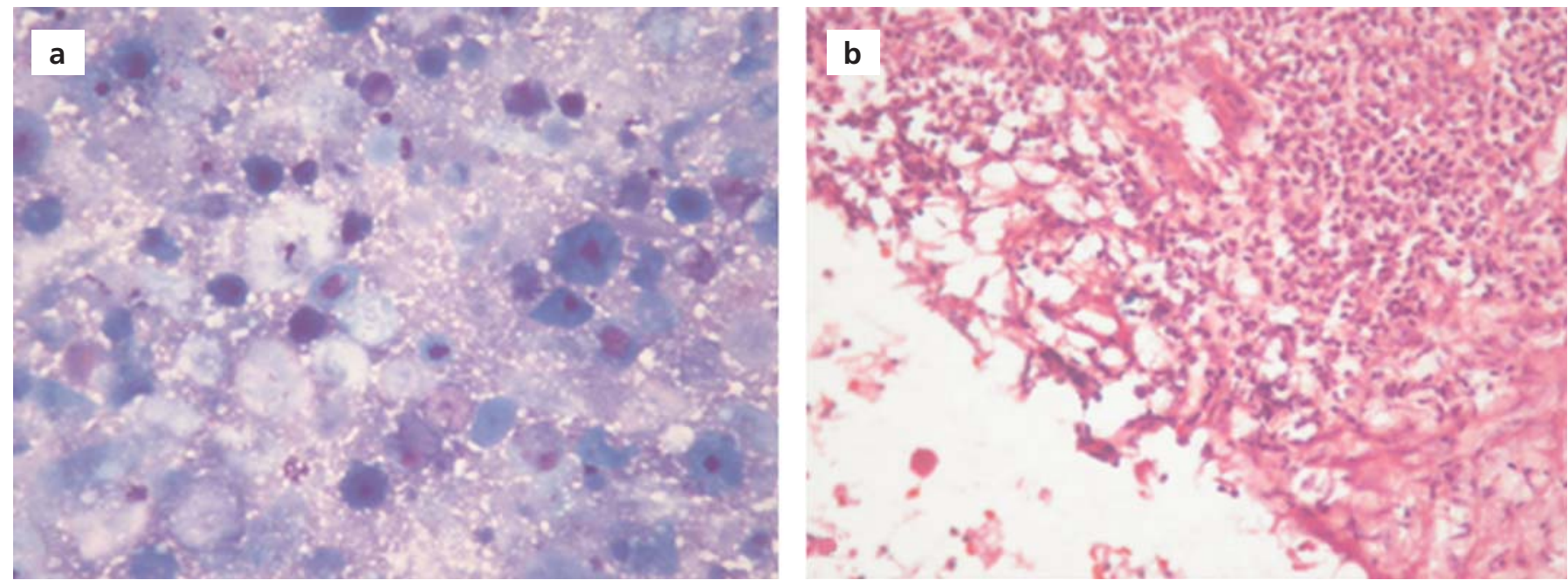

Fig. 1. Fine needle aspiration cytology of Case 1 (a) demonstrating hyperchromatic squamous epithelium with large nuclei, inflammatory elements mainly composed of lymphocytes, and anuclear squamous components on a necrotic background (Giemsa x20). Postoperative histopathologic appearance of Case 1 (b) demonstrating lymphoid elements, and inflammatory cells on the cyst wall lined with multilayered squamous epithelium with patchy areas of desquamation (HE x20).

We deemed it appropriate to present the findings, and management results of our three patients treated in our clinics for brachial cleft cysts, whose repetitive FNA biopsy results were submitted as metastatic SCC, but complied clinically with brachial cleft cyst.

\section{Case Reports}

\section{Case 1}

A 35-year-old female patient consulted to us with a swelling on the right side of her neck persisting for two months. Her physical examination revealed a palpable, non-pulsatile, non-fluctuant, painless, and mobile mass with a consistency of a rubber localized at the posterior aspect of the right mandibular angle without any evidence of fixation to the skin or deeper layers whose dimensions did not change with straining. Magnetic resonance imaging (MRI) results were interpreted as a cystic mass suggestive of a cystic tumor originating from the parotid gland. The result of the first FNA biopsy was interpreted as an evidence of a malign cytology (Fig. 1a). Subsequently, the patient had undergone panendoscopy, and nasopharyngeal blind biopsy. A second FNA biopsy, performed because of still undefined primary focus, was reported as a metastatic lesion of a cystic SCC. Due to inconclusive results, nasopharyngeal biopsy was repeated and histopathologic result was recorded as a benign lesion. Accordingly, surgery was performed, and intraoperative frozen section examination revealed a benign lesion, which urged us to extirpate the mass. Postoperative histopathologic examination was reported as brachial cleft cyst (Fig. 1b).

\section{Case 2}

A 40-year-old male patient consulted to our clinics with complaints of a swelling on his neck persisting for some time. The result of his FNA biopsy was reported as suspect cytology, and tissue correlation was suggested for differential diagnosis between metastatic SCC and lymphoma (Fig. 2). However, it was learnt that the patient had been operated in another medical center, and the mass lesion had been diagnosed as a brachial cyst.

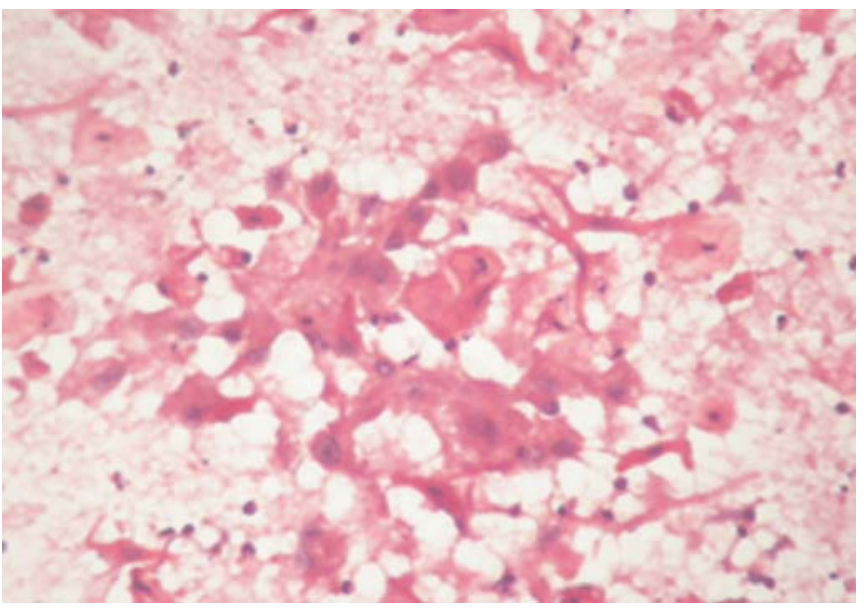

Fig. 2. Cytologic examination of the fine needle aspiration biopsy in Case 2 demonstrating necrotic changes on a dirty background, squamatoid cells with dark hyperchromatic nuclei, and eosinophilic dense cytoplasm in loose cohesive groups or isolated cells some of them with elongated cytoplasms, and lymphocytes (HE x20). 


\section{Case 3}

A 48-year-old male patient referred to our clinics with complaints of a swelling on his neck persisting for nearly five months. His physical examination disclosed a palpable solid mass on the right side of the neck extending superiorly from the lower edge of mandible down to the lower level of the thyroid cartilage. His cervical computed tomography (CT) findings were interpreted in favor of a hypodense LAP. US findings were interpreted as a solid mass. The report of the FNA biopsy performed indicated suspect cytology, and tissue correlation was recommended to make a differential diagnosis between well-differentiated SCC, and brachial cleft cyst (Fig. 3a). Therefore, frozen section was planned, and operation was decided upon. Frozen section examination revealed a benign mass, and the operation was terminated after extirpation of the mass. Postoperative histopathologic diagnosis was reported as brachial cleft cyst (Fig. 3b).

\section{Discussion}

Fine-needle aspiration cytology is an accurate technique for evaluating enlarged, solid, cervical nodes with very low (1-3\%) false-positive and false-negative rates. ${ }^{[5]}$ However, in cystic lesions, it may be difficult, or sometimes impossible, to distinguish between benign and malignant squamous cells in aspirates, which, then, results in a high falsenegative rate. ${ }^{[2,6]}$ On the one hand, this diagnostic dilemma is related to reactive squamous atypia secondary to super- imposed inflammation; this atypia can closely simulate a squamous malignancy. ${ }^{[3]}$ Conversely, metastatic SCC may be well differentiated and display cytologically bland features that mimic benign lesions, such as keratinous cysts or epidermal inclusion cysts. ${ }^{[4]} \mathrm{A}$ false-negative FNA cytology finding is likely to delay both the search for a primary tumor and adequate therapy. In contrast, the consequences of a false-positive diagnosis of metastatic SCC on FNA may include unnecessary surgical procedures such as radical neck dissection.

While a FNA biopsy may aid diagnosis, it has been reported that branchial cysts if inflamed can show both cellular and nuclear pleomorphism when FNA examination has been undertaken, such that the appearances can be mistaken for a well-differentiated SCC. ${ }^{[7,8]}$ For this reason, most of the time, tests, and time spent to search for the primary focus are wasted. These frustrating efforts also delay proper treatment of the patient. Main factors facilitating establishment of a misdiagnosis are advanced age of the patient, and the presence of an inflammatory mass at the time of diagnosis. A series consisting of 42 patients demonstrated the presence of malignancy in $80 \%$ of the patients over 40 years of age, and despite FNA biopsies performed, the authors arrived at an accurate peroperative diagnosis in only three out of nine patients with different malignancies. While in the remaining six cases, correct diagnosis of malignancy could only be made after postoperative histopathologic examination of the specimens. This study gives an idea about reliability of FNA biopsy. ${ }^{\left[{ }^{[]}\right.}$
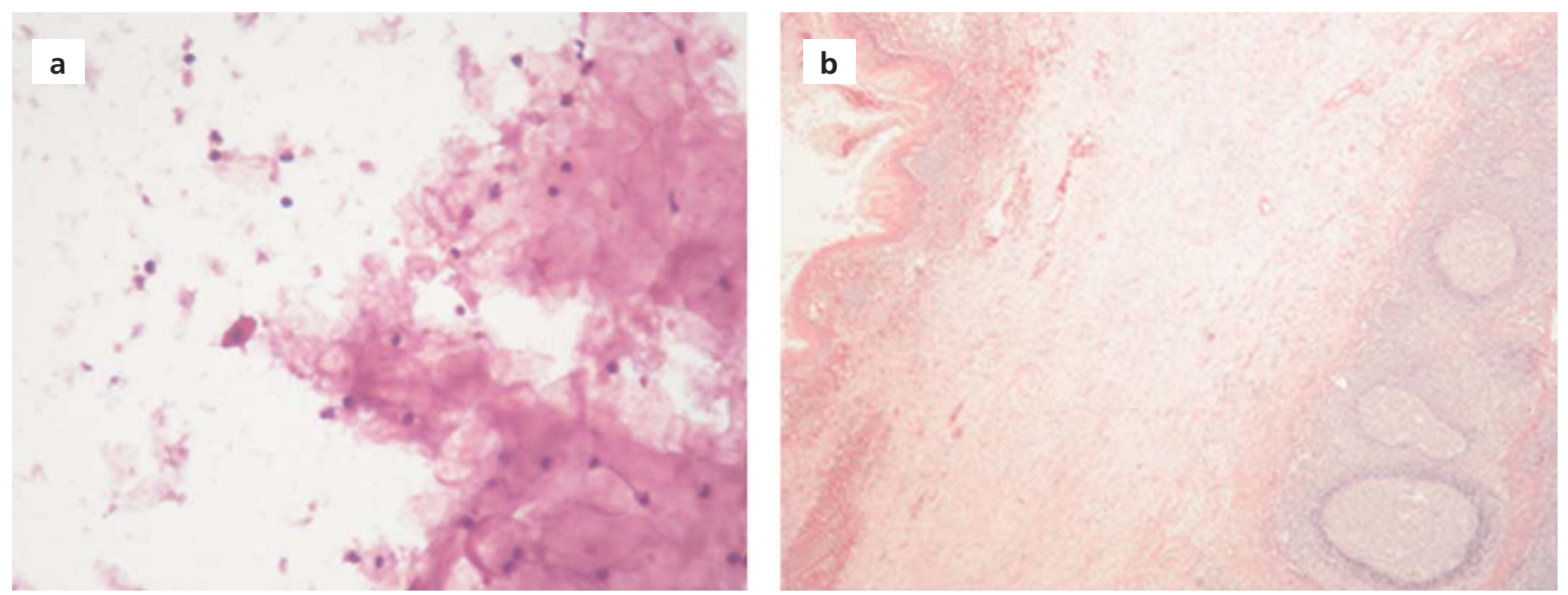

Fig. 3. Fine needle aspiration cytology of Case 3 (a) demonstrating squamous epithelium, and lymphocytes demonstrating patchy areas of nuclear atypia on a dirty background (HE x20). Histopathologic appearance of the surgical specimen in Case 3 (b) demonstrating lymphoid tissue islets in aggregates on the walls of the cyst lined with multilayered squamous epithelium (HE x10). 
Ultrasound, CT or MRI scans of metastatic lesions will often reveal irregular thicker walls, heterogeneous internal debris or septation of the walls, which would not be expected in branchial cysts, although the differentiation is more difficult in infected branchial cysts. ${ }^{[10]}$ Imaging techniques used for these patients can yield incorrect results. In fact, in our Case 1, MRI performed wrongly defined brachial cyst as a cystic tumor originating from parotid gland.

Another factor leading to misdiagnosis is the emergence of the cyst at an unexpected location with unusual manifestations. In the literature, a 45-year-old male patient who presented with cystic erosion of the skull base, and conductive hearing loss is cited. ${ }^{[11]}$ As indicated before, in a 77-year-old patient, salivary gland, and lymphoid tissue were detected on the cyst wall which could be diagnosed preoperatively. ${ }^{[12]}$

Since we experienced uncertainties during diagnostic process and also clinical manifestations suggested a benign event in addition to benign frozen section examination results of surgical specimens of both patients, we terminated the operation after excision of cysts.

Herein, we aimed to highlight a diagnostic pitfall with some disastrous consequences. The cytological appearances of an FNA sample may require interpretation by an experienced cytologist, because the differences between metastatic squamous cell carcinoma and inflamed branchial cyst can be subtle and relate to the appearances of the nuclear outline and hyperchromatism. In patients whose FNA biopsy results are reported as definitive or suspect SCC metastasis, it will be appropriate to start with the surgical procedure without discarding the possibility of a brachial cleft cyst, and also frozen section results should guide further steps of the surgical procedure.

Conflict of Interest: No conflicts declared.

\section{References}

1. van den Brekel MW, Castelijns JA, Stel HV, et al. Occult metastatic neck disease: detection with US and US guided fineneedle aspiration cytology. Radiology 1991;180:457-61.

2. Engzell U, Zajicek J. Aspiration biopsy of tumors of the neck. I. Aspiration biopsy and cytologic findings in 100 cases of congenital cysts. Acta Cytol 1970;14:51-7.

3. Burgess KL, Hartwick RW, Bedard YC. Metastatic squamous carcinoma presenting as a neck cyst. Differential diagnosis from inflamed branchial cleft cyst in fine needle aspirates. Acta Cytol 1993;37:494-8.

4. Thompson HY, Fulmer RP, Schnadig VJ. Metastatic squamous cell carcinoma of the tonsil presenting as multiple cystic neck masses. Report of a case with fine needle aspiration findings. Acta Cytol 1994;38:605-7.

5. Engzell U, Jakobsson PA, Sigurdson A, Zajicek J. Aspiration biopsy of metastatic carcinoma in lymph nodes of the neck. A review of 1101 consecutive cases. Acta Otolaryngol 1971;72:138-47.

6. Granstrom G, Edstrom S. The relationship between cervical cysts and tonsillar carcinoma in adults. J Oral Maxillofac Surg 1989;47:16-20.

7. Warson F, Blommaert D, De Roy G. Inflamed branchial cyst: a potential pitfall in aspiration cytology. Acta Cytol 1986;30:201-2.

8. Burgess KL, Hartwick RWJ, Bedard YC. Metastatic squamous carcinoma presenting as a neck cyst. Differential diagnosis from inflamed branchial cysts. Acta Cytol 1993;37:494-8.

9. Granstrom G, Edstrom S. The relationship between cervical cysts and tonsillar carcinoma in adults. J Oral Maxillofac Surg 1989;47:16-20.

10. Ahuja A, Ng CF, King W, Metreweli C. Solitary cystic nodal metastasis from occult papillary carcinoma of the thyroid mimicking a branchial cyst: a potential pitfall. Clin Radiol 1998;53:61-3.

11. Ahn JY, Kang SY, Lee CH, Yoon PH, Lee KS. Parapharyngeal branchial cleft cyst extending to the skull base: a lateral transzygomatic-transtemporal approach to the parapharyngeal space. Neurosurg Rev 2005;28:73-6.

12. Takita M, Hamaguchi H, Lin YT, et al. Lymphoepithelial cyst of the upper neck: report of a case. Osaka Daigaku Shigaku Zasshi 1989;34:431-7.

This is an open access article distributed under the terms of the Creative Commons Attribution-NonCommercial-NoDerivs 3.0 Unported (CC BYNC-ND3.0) Licence (http://creativecommons.org/licenses/by-nc-nd/3.0/) which permits unrestricted noncommercial use, distribution, and reproduction in any medium, provided the original work is properly cited.

Please cite this article as: Songu M, Aslan H, Başoğlu S, Öztürkcan S, Etit D. Branchial cleft cyst presenting as metastatic squamous carcinoma in fine needle aspirates: report of three cases. J Med Updates 2013;3(1):40-43. 